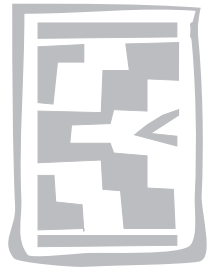

\title{
Ixodid ticks on dogs belonging to people in rural communities and villages in Maputo Province, Mozambique
}

\author{
C. DE MATOS ${ }^{1}$, C. SITOE ${ }^{2}$, L. NEVES ${ }^{3}$, N.R. BRYSON ${ }^{4}$ and I.G. HORAK ${ }^{5 *}$
}

\begin{abstract}
DE MATOS, C., SITOE, C., NEVES, L., BRYSON, N.R. \& HORAK, I.G. 2008. Ixodid ticks on dogs belonging to people in rural communities and villages in Maputo Province, Mozambique. Onderstepoort Journal of Veterinary Research, 75:103-108

The species composition and geographic distribution of ixodid ticks infesting domestic dogs owned by people in rural communities and villages in Maputo Province was established by collecting ticks from dogs at each of 27 localities spread throughout the province. Ticks were collected from a total of 132 dogs, and nine species belonging to four genera were identified. One dog was infested with six species, three with five and 13 with four species. Haemaphysalis elliptica followed by Rhipicephalus simus were present on dogs at most localities, and their geographic distribution in Maputo Province has been mapped for the first time.
\end{abstract}

Keywords: Dogs, geographic distribution, Haemaphysalis elliptica, ixodid ticks, Maputo Province, Mozambique, Rhipicephalus simus

\section{INTRODUCTION}

A single survey on the ticks that infest dogs has been conducted in Zimbabwe, another in Mozam-

* Author to whom correspondence is to be directed: E-mail: ivan.horak@up.ac.za

1 Direcção de Ciências Animais, Instituto de Investigação Agrária de Mozambique, C.P. 1922, Maputo, Mozambique, and Department of Veterinary Tropical Diseases, Faculty of Veterinary Science, University of Pretoria, Private Bag X04, Onderstepoort, 0110 South Africa

2 Direcção de Ciências Animais, Instituto de Investigação Agrária de Mozambique, C.P. 1922, Maputo, Mozambique

3 Faculdade de Veterinária, Universidade Eduardo Mondlane, C.P. 257, Maputo, Mozambique

4 Department of Veterinary Tropical Diseases, Faculty of Veterinary Science, University of Pretoria, Private Bag X04, Onderstepoort, 0110 South Africa

5 Department of Veterinary Tropical Diseases, Faculty of Veterinary Science, University of Pretoria, Private Bag X04, Onderstepoort, 0110 South Africa, and ARC-Onderstepoort Veterinary Institute, Onderstepoort, 0110 South Africa, and Department of Zoology and Entomology, University of the Free State, P.O. Box 339, Bloemfontein, 9300 South Africa

Accepted for publication 14 January 2008-Editor bique, while seven such surveys have been conducted in South Africa, and a total of 24 ixodid and one argasid tick species recovered (Goldsmid 1963; Horak, Jacot Guillarmod, Moolman \& De Vos 1987b; Horak 1995; Bryson, Horak, Höhn \& Louw 2000; Horak, Emslie \& Spickett 2001; Jacobs, Fourie, Kok \& Horak 2001; Horak \& Matthee 2003; Neves, Afonso \& Horak 2004; Nyangiwe, Horak \& Bryson 2006). In addition to the above 24 species, Dias (1991) has recorded Amblyomma tholloni, a tick of African elephants, and Rhipicephalus meuhlensi, a tick of nyalas, on dogs in Mozambique. Subsequent to the above-mentioned surveys, one of the most commonly encountered ticks on dogs in southern Africa, namely Haemaphysalis leachi, has been reinstated as Haemaphysalis elliptica, an old taxon from the Cape of Good Hope (Apanaskevich, Horak \& Camicas 2007). With the exception of the ticks in the surveys conducted by Goldsmid (1963) and Jacobs et al. (2001), the majority of ticks identified as $H$. leachi in the afore-mentioned surveys have been re-examined and re-identified as $H$. elliptica (Apanaskevich et al. 2007). 
During the course of surveys conducted in South Africa, the seasonal abundances of Haemaphysalis elliptica, Rhipicephalus gertrudae, Rhipicephalus sanguineus and Rhipicephalus simus have been determined on dogs (Horak 1982; Horak et al. 1987b, 2001; Jacobs et al. 2001; Horak \& Matthee 2003). With the exception of $R$. sanguineus, the geographic distributions of these ticks in South Africa have been mapped (Howell, Walker \& Nevill 1978; Walker, Keirans \& Horak 2000).

The adults of the abovementioned five ticks, and those of the Ixodes pilosus group and of Ixodes rubicundus, may use dogs as hosts (Horak et al. 1987b; Jacobs et al. 2001; Horak \& Matthee 2003). However, with the exception of the adults of $R$. sanguineus, they may also infest other animals (Walker 1991). As is the case with the adults, the immature stages of $R$. sanguineus infest only dogs (Walker et al. 2000), while those of the I. pilosus group infest dogs and a variety of small and large mammals (Walker 1991). The immature stages of I. rubicundus infest elephant shrews, Elephantulus spp., and Smith's red rock rabbits, Pronolagus rupestris (Stampa 1959; Fourie, Horak \& Woodall 2005), whereas those of the other species nearly exclusively infest rodents (Norval \& Mason 1981; Norval 1984; Matthee, Horak, Beaucornu, Durden, Ueckermann \& McGeogh 2007).

Most of the dogs in the survey conducted in Mozambique by Neves et al. (2004) were examined in the Province of Maputo. This is the southernmost province and has a seaboard of approximately $320 \mathrm{~km}$, and the landscape rises from the Indian Ocean in the east to about $800 \mathrm{~m}$ above sea level in the west. The vegetation along the coast is described as shrubland with patches of wetland, mangrove and deciduous trees along river shores and on dunes. Inland it is dominated by woodland, and in the north-west district of Magude by associations of savannah and mopane (Colophospermum mopane). The inland vegetation of the south was characterized by forest that has been extensively denuded for the production of charcoal. The southern border of the province abuts on north-eastern KwaZulu-Natal Province, South Africa, where a survey of the ticks infesting dogs belonging to persons in rural communities has been conducted (Horak et al. 2001). The western border of Maputo Province adjoins the eastern border of the Kruger National Park, South Africa, in which a survey on the ticks infesting wild carnivores has been conducted (Horak, Braack, Fourie \& Walker 2000). The present communication records the results of a tick survey conducted on domestic dogs owned by people in 27 rural communities and villages spread throughout the Province of Maputo.

\section{MATERIALS AND METHODS}

Thirty rural communal cattle dip-tanks or villages, evenly spread throughout Maputo Province were selected for the survey. Ticks were to be collected, whenever possible, from five dogs at each of these localities. In addition, ticks were collected from 24 dogs at two villages in south-western Maputo Province during a rabies inoculation campaign, as well as from two dogs at two villages in the south-east of the province. To minimize stress to the dogs as well as injuries to the researchers during the collections, the animals were usually muzzled and thereafter restrained by their owners. The ticks were stored in $70 \%$ ethyl alcohol in internally labelled vials for later identification and counting. The geographic coordinates of each locality at which ticks were collected were recorded and used to plot the distributions of the two most commonly collected species, namely $H$. elliptica and R. simus.

\section{RESULTS AND DISCUSSION}

No dogs were available at seven of the chosen localities, and less than five dogs were examined at five. A total of 132 dogs was examined and 1768 ticks were collected. Of the nine species that could be identified, $H$. elliptica and $R$. simus were the most numerous and the most widely distributed (Table 1, Fig. 1). One of the dogs was infested with six tick species, three with five and 13 with four species, and the largest number of ticks collected from a single dog was 41 . Combining the results of the present survey with those of the survey conducted by Neves et al. (2004) and the ticks listed by Dias (1991), a total of 16 tick species has now been collected from dogs in Mozambique.

\section{Amblyomma hebraeum}

Adult ticks of this species prefer large herbivorous animals as hosts (Norval 1983; Horak, Maclvor, Petney \& De Vos 1987a; Horak, Golezardy \& Uys 2007). These large ticks are also occasionally found on dogs and other medium-sized animals, particularly when the former are in poor health, as some of the dogs in the present survey were. The larvae infest a large variety of hosts, including large and small herbivores, carnivores and ground-frequenting birds, while some of these animals are also infested by nymphs (Norval 1983; Horak et al. 1987a, 2000). 
The immature stages are almost invariably present on free-running domestic dogs within the tick's distribution range in rural areas in southern Africa (Horak et al. 1987b, 2001; Neves et al. 2004; Nyangiwe et al. 2006). Although the present survey was designed to collect adult ticks, some larvae and a fairly large number of $A$. hebraeum nymphs were recovered, undoubtedly because of the latter's large size, particularly when they are engorged.

\section{Haemaphysalis elliptica}

This tick has been collected from dogs in all the surveys conducted in South Africa as well as in the one previously conducted in Mozambique. Not only was it present on dogs at all except two of the 27 sampling localities in the current survey, but it was recovered from 100 of the 132 dogs examined (Fig. $1 \mathrm{~A}$, Table 1). Free-ranging domestic dogs and the larger wild felids are particularly susceptible to infestation with the adults of $\mathrm{H}$. elliptica (Horak et al. 1987b, 2000, 2001; Neves et al. 2004). Its immature stages infest murid rodents and have been collected from these animals in many regions of South Africa (Fourie, Horak \& Van den Heever 1992; Braack, Horak, Jordaan, Segerman \& Louw 1996; Petney, Horak, Howell \& Meyer 2004; Horak, Fourie \& Braack 2005; Matthee et al. 2007). However, no systematic collections of ticks from these small mammals appear to have been done in Mozambique.

Haemaphysalis elliptica is widely distributed in South Africa (Howell et al. 1978) and its distribution extends into southern Mozambique and Zimbabwe (Apanaskevich et al. 2007). Its presence in the southern part of the country is confirmed by the present survey (Fig. 1A). In central and northern Mozambique its distribution overlaps that of the southern distribution of Haemaphysalis leachi sensu strictu (Apanaskevich et al. 2007).

In the past it was presumed that $H$. leachi was responsible for the transmission of Babesia canis rossi, the cause of virulent babesiosis in domestic dogs in South Africa (Lewis, Penzhorn, Lopez-Rebol-

TABLE 1 Ticks collected from 132 dogs at 27 rural localities in Maputo Province, Mozambique

\begin{tabular}{|c|c|c|c|c|c|c|c|}
\hline \multirow{2}{*}{ Tick species } & \multirow{2}{*}{$\begin{array}{l}\text { No. of } \\
\text { positive } \\
\text { localities }\end{array}$} & \multirow{2}{*}{$\begin{array}{l}\text { No. of } \\
\text { dogs } \\
\text { infested }\end{array}$} & \multicolumn{5}{|c|}{ Number of ticks collected } \\
\hline & & & Larvae & Nymphs & Males & Females & Total \\
\hline Amblyomma hebraeum & 16 & 57 & 48 & 195 & 24 & 4 & 271 \\
\hline Haemaphysalis elliptica & 26 & 100 & 0 & 9 & 252 & 331 & 592 \\
\hline Haemaphysalis spp. & 4 & 6 & 0 & 0 & 3 & 4 & 7 \\
\hline Ixodes cavipalpus & 1 & 2 & 0 & 0 & 1 & 2 & 3 \\
\hline Rhipicephalus appendiculatus & 7 & 13 & 0 & 37 & 2 & 0 & 39 \\
\hline Rhipicephalus evertsi evertsi & 2 & 2 & 0 & 0 & 2 & 1 & 3 \\
\hline Rhipicephalus pravus group & 1 & 1 & 0 & 0 & 0 & 2 & 2 \\
\hline Rhipicephalus sanguineus & 8 & 21 & 1 & 8 & 120 & 67 & 196 \\
\hline Rhipicephalus simus & 24 & 98 & 0 & 0 & 334 & 259 & 593 \\
\hline Rhipicephalus turanicus & 9 & 22 & 0 & 0 & 39 & 23 & 62 \\
\hline
\end{tabular}

A
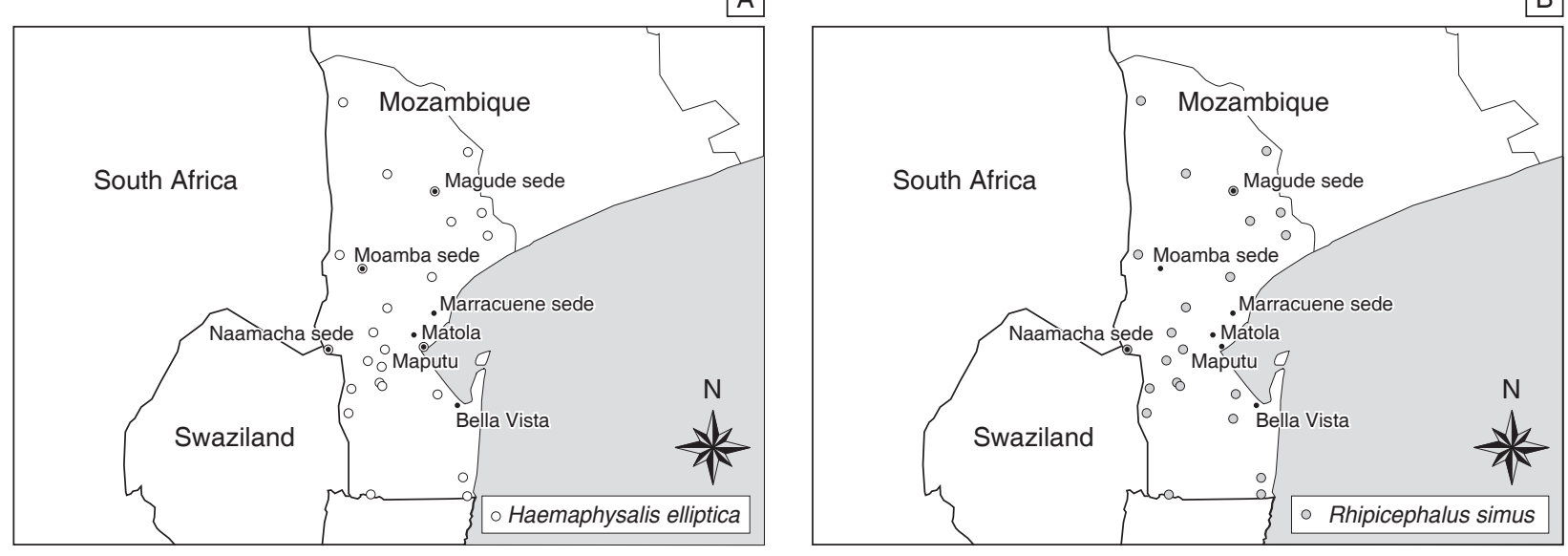

FIG. 1 Localities at which (A) Haemaphysalis elliptica and (B) Rhipicephalus simus were collected from dogs in Maputo Province, Mozambique 
lar \& De Waal 1996). It is now apparent that Lewis et al. (1996) conducted their experiments with $H$. elliptica and that it is this tick that is the vector of $B$. canis rossi (Apanaskevich et al. 2007). The role of $H$. leachi sensu strictu as a vector of $B$. canis rossi or other pathogenic organisms that may affect domestic dogs still needs clarification.

\section{Ixodes cavipalpus}

According to Walker (1991) I. cavipalpus is probably the most widely distributed Ixodes sp. in the Afrotropical region. Amongst a variety of other hosts, it has been collected from both small and large domestic and wild carnivores (Theiler 1962; Walker 1991), and two males and six females have been collected from domestic dogs in Harare, Zimbabwe (Goldsmid 1963). In the present survey, the only collections consisted of a single male and two females taken from dogs at the Mahubo dip-tank between Boane and Bela Vista in the south of the province. Not only dogs, but also cattle and goats examined at the same locality were infested.

\section{Rhipicephalus appendiculatus}

Adult $R$. appendiculatus infests cattle, goats and large wild bovids (Walker et al. 2000; Nyangiwe \& Horak 2007), and its immature stages are found on the same hosts as the adults as well as on smaller bovids and scrub hares (Horak \& Fourie 1991; Walker et al. 2000). All stages of development may, however, infest domestic dogs and wild carnivores (Goldsmid 1963; Horak et al. 2000, 2001; Nyangiwe et al. 2006). In the present study, nymphs and males were collected from 13 dogs at seven localities.

Infestation of dogs with this tick species has, in isolated instances, epidemiological implications for the transmission of Theileria parva, the cause of East Coast fever and Corridor disease in domestic cattle (Lawrence, Perry \& Williamson 2004). Many resource-limited rural hunters use dogs to run down their prey, often cutting, or lifting fences between farms to gain access to wildlife. The dogs could either introduce $R$. appendiculatus onto a previously tick-free property, or acquire infestation during the hunt and bring the ticks back to their owner's property.

\section{Rhipicephalus sanguineus}

All stages of development of $R$. sanguineus infest domestic dogs (Horak 1982), which Walker et al. (2000) believe are its only true hosts. Although our collections focused on adult ticks, one larva and eight nymphs were collected, confirming the host preference of these stages. The tick's life cycle is adapted to the resting places of dogs in man-made structures such as sheds, dog kennels and human dwellings (Howell et al. 1978; Horak 1982). Its prevalence and intensity of infestation are significantly higher on city or urban dogs, which are usually confined to the properties of their owners, than on rural dogs (Neves et al. 2004). Its presence on 21 dogs at eight of the rural sampling localities in the present survey suggests that these animals were at least for some part of the day, chained, or caged at the homes of their owners.

\section{Rhipicephalus simus}

Adult $R$. simus has a preference for domestic and wild carnivores, zebras, Equus spp., warthogs, Phacochoerus africanus, and domestic cattle (Walker et al. 2000). In a recent survey conducted in the Eastern Cape Province, South Africa, 29 dogs at 14 sampling localities were infested with this tick (Nyangiwe et al. 2006), whereas no $R$. simus were collected from 360 cattle at 72 localities, including the 14 at which dogs were infested (Nyangiwe \& Horak, unpublished data 2007). In the present study there also appeared to be a slight preference for dogs rather than for cattle, in that $R$. simus was collected from 98 dogs $(74.2 \%)$ of the 132 examined compared to 102 cattle $(70.3 \%)$ of 145 examined. Its immature stages infest murid rodents (Norval \& Mason 1981; Braack et al. 1996; Horak et al. 2005), and it is thus more common on dogs in rural environments, where rodents are likely to be plentiful, than on city or urban dogs (Horak et al. 1987b, 2001; Neves et al. 2004).

With the exception of the Sabie dip-tank in the central western region of Maputo Province, the Chiango dip-tank in the east, and one of the villages in the south-east, $R$. simus was present on dogs throughout the province (Fig. 1B). This distribution lies within that mapped for this tick in southern Africa (Walker et al. 2000).

\section{Rhipicephalus turanicus}

Like $R$. sanguineus, $R$. turanicus has a very widespread distribution outside Africa, and these two ticks are often mistaken for each other, particularly as the adults of both infest domestic dogs (Walker et al. 2000). Unlike $R$. sanguineus, however, $R$. turanicus does not make use of man-made structures as an integral part of its life cycle. Furthermore, whereas $R$. sanguineus infests only domestic dogs during all stages of development, adult $R$. turanicus 
infests a variety of hosts in addition to domestic dogs, amongst these are cats, sheep, goats, horses, wild carnivores, hares and birds, and its immature stages probably infest rodents and other small mammals, but not dogs (Horak, Spickett, Braack, Penzhorn, Bagnall \& Uys 1995; Horak et al. 2000; Walker et al. 2000). Because $R$. turanicus is a parasite of wildlife as well as domestic animals, it is encountered on animals in suburban, rural and wildlife environments (Walker et al. 2000). Moreover, it would seem from the restricted late summer abundance of its adults (Horak et al. 2001), that it is only likely to complete one life cycle annually in South Africa, whereas $R$. sanguineus often completes more than one (Horak 1982; Horak \& Matthee 2003).

\section{ACKNOWLEDGEMENTS}

We express our sincere appreciation to the Directorate of Animal Science, Mozambique for permitting C. de Matos and C. Sitoe to conduct this survey as part of their official duties. We are most grateful to the dog owners who assisted with the collection of ticks from their animals, and to Dr Roy Williams of the ARC-Onderstepoort Veterinary Institute for mapping the distribution of the ticks. The project was financed by funds provided to $C$. de Matos by the SIDA/SAREC-Joint Inive-Veternary Faculty Research Project \# 27, and by funds provided to I.G. Horak by the National Research Foundation.

\section{REFERENCES}

APANASKEVICH, D.A., HORAK, I.G. \& CAMICAS, J.-L. 2007. Redescription of Haemaphysalis (Rhipistoma) elliptica (Koch, 1844), an old taxon of the Haemaphysalis (Rhipistoma) leachi group from East and southern Africa, and of Haemaphysalis (Rhipistoma) leachi (Audouin, 1826) (Ixodida, Ixodidae). Onderstepoort Journal of Veterinary Research, 74:181-208.

BRAACK, L.E.O., HORAK, I.G., JORDAAN, LEONORA C., SEGERMAN, JOYCE \& LOUW, J.P. 1996. The comparative host status of red veld rats (Aethomys chrysophilus) and bushveld gerbils (Tatera leucogaster) for epifaunal arthropods in the southern Kruger National Park, South Africa. Onderstepoort Journal of Veterinary Research, 63:149-158.

BRYSON, N.R., HORAK, I.G., HÖHN, E.W. \& LOUW, J.P. 2000. Ectoparasites of dogs belonging to people in resource-poor communities in North West Province, South Africa. Journal of the South African Veterinary Association, 71:175-179.

DIAS, J.A. TRAVASSOS SANTOS. 1991 (1993). Some data concerning the ticks (Acarina, Ixodoidea) presently known in Mozambique. Garcia de Orta, Séries Zoologica, Lisboa, 18: 27-48.

FOURIE, L.J., HORAK, I.G. \& VAN DEN HEEVER, J.J. 1992. The relative host status of rock elephant shrews Elephantulus myurus and Namaqua rock mice Aethomys namaquensis for economically important ticks. South African Journal of Zoology, 27:108-114.
FOURIE, L.J., HORAK, I.G. \& WOODALL, P.F. 2005. Elephant shrews as hosts of immature ixodid ticks. Onderstepoort Journal of Veterinary Research, 72:293-301.

GOLDSMID, J.M. 1963. Ticks infesting dogs in the Salisbury area of Southern Rhodesia. Journal of the South African Veterinary Medical Association, 34:609-610.

HORAK, I.G. 1982. Parasites of domestic and wild animals in South Africa. XIV. The seasonal prevalence of Rhipicephalus sanguineus and Ctenocephalides spp. on kennelled dogs in Pretoria North. Onderstepoort Journal of Veterinary Research, 49:63-68.

HORAK, I.G., MACIVOR, K.M. DE F., PETNEY, T.N. \& DE VOS, V. 1987a. Some avian and mammalian hosts of Amblyomma hebraeum and Amblyomma marmoreum (Acari: Ixodidae). Onderstepoort Journal of Veterinary Research, 54:397-403.

HORAK, I.G., JACOT GUILLARMOD, AMY, MOOLMAN, L.C. \& DE VOS, V. 1987b. Parasites of domestic and wild animals in South Africa. XXII. Ixodid ticks on domestic dogs and on wild carnivores. Onderstepoort Journal of Veterinary Research, 54:573-580.

HORAK, I.G. \& FOURIE, L.J. 1991. Parasites of domestic and wild animals in South Africa. XXIX. Ixodid ticks on hares in the Cape Province and on hares and red rock rabbits in the Orange Free State. Onderstepoort Journal of Veterinary Research, 58:261-270.

HORAK, I.G. 1995. Ixodid ticks collected at the Faculty of Veterinary Science, Onderstepoort, from dogs diagnosed with Babesia canis infection. Journal of the South African Veterinary Association, 66:170-171.

HORAK, I.G., SPICKETT, A.M., BRAACK, L.E.O., PENZHORN, B.L., BAGNALL, R.J. \& UYS, A.C. 1995. Parasites of domestic and wild animals in South Africa. XXXIII. Ixodid ticks on scrub hares in the north-eastern regions of Northern and Eastern Transvaal and of KwaZulu-Natal. Onderstepoort Journal of Veterinary Research, 62:123-131.

HORAK, I.G., BRAACK, L.E.O., FOURIE, L.J. \& WALKER, JANE B. 2000. Parasites of domestic and wild animals in South Africa. XXXVIII. Ixodid ticks collected from 23 wild carnivore species. Onderstepoort Journal of Veterinary Research, 67: 239-250.

HORAK, I.G., EMSLIE, F.R. \& SPICKETT, A.M. 2001. Parasites of domestic and wild animals in South Africa. XL. Ticks on dogs belonging to people in rural communities and carnivore ticks on the vegetation. Onderstepoort Journal of Veterinary Research, 68:135-141.

HORAK, I.G. \& MATTHEE, SONJA 2003. Parasites of domestic and wild animals in South Africa. XLIII. Ixodid ticks of domestic dogs and cats in the Western Cape Province. Onderstepoort Journal of Veterinary Research, 70:187-195.

HORAK, I.G., FOURIE, L.J. \& BRAACK, L.E.O. 2005. Small mammal hosts of immature ixodid ticks. Onderstepoort Journal of Veterinary Research, 72:255-261.

HORAK, I.G., GOLEZARDY, H. \& UYS, A.C. 2007. Ticks associated with the three largest wild ruminant species in southern Africa. Onderstepoort Journal of Veterinary Research, 74: 231-242.

HOWELL, C.J., WALKER, JANE B. \& NEVILL, E.M. 1978. Ticks, mites and insects infesting domestic animals in South Africa. Part 1. Descriptions and biology. Pretoria, Republic of South Africa: Department of Agricultural Technical Services (Science Bulletin, no. 393).

JACOBS, P.A.H., FOURIE, L.J., KOK, D.J. \& HORAK, I.G. 2001. Diversity, seasonality and sites of attachment of adult ixodid ticks on dogs in the central region of the Free State Province, 
South Africa. Onderstepoort Journal of Veterinary Research, 68:281-290.

LAWRENCE, J.A., PERRY, B.D. \& WILLIAMSON, S.M. 2004. Corridor disease, in Infectious diseases of livestock, $2^{\text {nd }}$ ed., edited by J.A.W. Coetzer \& R.C. Tustin, Cape Town: Oxford University Press Southern Africa.

LEWIS, B.D., PENZHORN, B.L., LOPEZ-REBOLLAR, L.M. \& DE WAAL, D.T. 1996. Isolation of a South African vector-specific strain of Babesia canis. Veterinary Parasitology, 63:9-16.

MATTHEE, S., HORAK, I.G., BEAUCOURNU, J.-C., DURDEN, L.A., UECKERMANN, E.A. \& MCGEOCH, M.A. 2007. Epifaunistic arthropod parasites of the four-striped mouse, Rhabdomys pumilio, in the Western Cape Province, South Africa. Journal of Parasitology, 93:147-159.

NEVES, L., AFONSO, SONIA \& HORAK, I.G. 2004. Ixodid ticks on dogs in and around Maputo and elsewhere in Mozambique. Onderstepoort Journal of Veterinary Research, 71:279-283.

NORVAL, R.A.I. \& MASON, C.A. 1981. The ticks of Zimbabwe. II. The life cycle, distribution and hosts of Rhipicephalus simus Koch, 1844. Zimbabwe Veterinary Journal, 12:2-9.

NORVAL, R.A.I. 1983. The ticks of Zimbabwe. VII. The genus Amblyomma. Zimbabwe Veterinary Journal, 14:292-305.

NORVAL, R.A.I. 1984. The ticks of Zimbabwe. IX. Haemaphysalis leachi and Haemaphysalis spinulosa. Zimbabwe Veterinary Journal, 15:9-17.
NYANGIWE, N., HORAK, I.G. \& BRYSON, N.R. 2006. Ixodid ticks on dogs in the eastern region of the Eastern Cape Province, South Africa. Onderstepoort Journal of Veterinary Research, 73:305-309.

NYANGIWE, N. \& HORAK, I.G. 2007. Goats as alternative hosts of cattle ticks. Onderstepoort Journal of Veterinary Research, 74:1-7.

PETNEY, T.N., HORAK, I.G., HOWELL, D.J. \& MEYER, S. 2004. Striped mice, Rhabdomys pumilio, and other murid rodents as hosts for immature ixodid ticks. Onderstepoort Journal of Veterinary Research, 71:313-318.

STAMPA, S. 1959. Tick paralysis in the Karoo areas of South Africa. Onderstepoort Journal of Veterinary Research, 28: 169-227 + map.

THEILER, GERTRUD 1962. The Ixodoidea parasites of vertebrates in Africa south of the Sahara (Ethiopian region). Project S 9958. Report to the Director of Veterinary Services, Onderstepoort. Mimeographed.

WALKER, JANE B. 1991. A review of the ixodid ticks (Acari, Ixodidae) occurring in southern Africa. Onderstepoort Journal of Veterinary Research, 58:81-105.

WALKER, JANE B., KEIRANS, J.E. \& HORAK, I.G. 2000. The genus Rhipicephalus (Acari, Ixodidae): a guide to the brown ticks of the World. Cambridge: Cambridge University Press. 